九州大学学術情報リポジトリ

Kyushu University Institutional Repository

\title{
Association of Variation in the MC4R Gene with Meat Quality Traits in a Commercial Pig Population
}

\section{Kwon, Kang}

Department of Animal Science and Biotechnology, College of Agriculture and Life Sciences, Chungnam National University

Cahyadi, Muhammad

Department of Animal Science and Biotechnology, College of Agriculture and Life Sciences, Chungnam National University | Department of Animal Science, Faculty of Agriculture, Sebelas Maret University

\section{Park, Hee-Bok}

Department of Animal Science and Biotechnology, College of Agriculture and Life Sciences, Chungnam National University

\section{Seo, Dong Won}

Department of Animal Science and Biotechnology, College of Agriculture and Life Sciences, Chungnam National University

他

https://doi.org/10.5109/1526302

出版情報: 九州大学大学院農学研究院紀要. 60 (1)，pp.113-118，2015-02-27. Faculty of Agriculture, Kyushu University

バージョン：

権利関係 : 


\title{
Association of Variation in the $M C 4 R$ Gene with Meat Quality Traits in a Commercial Pig Population
}

\author{
Kang KWON ${ }^{1}$, Muhammad CAHYADI ${ }^{1,2}$, Hee-Bok PARK ${ }^{1}$, Dong Won SEO ${ }^{1}$, \\ Shil JIN ${ }^{1}$, Sang-Wook KIM ${ }^{3}$, Yang-Il $\mathrm{CHOI}^{3}$, Kwan Suk KIM ${ }^{3}$, \\ Takafumi GOTOH ${ }^{4}$ and Jun Heon LEE $^{1 *}$
}

Kuju Agricultural Research Center, Kyushu University, Kuju 4045-4, Taketa City, 878-020, Oita, Japan

(Received October 31, 2014 and accepted November 14, 2014)

\begin{abstract}
The melanocortin-4 receptor $(M C 4 R$ ) gene is known to encode a membrane-bound receptor protein and is a member of the melanocortin receptor family of genes. In mammals, these genes are involved in energy homeostasis and in regulating feeding behavior and body weight. The objective of the present study was to examine if there were any associations between variations in the $M C 4 R$ gene with meat quality traits in a commercial pig population in Korea. Among the total of 593 commercial pigs, sire information was retrieved from 232 pigs. These animals were successfully genotyped for the c.892A $>$ G (p.Asp298Asn) single nucleotide polymorphism (SNP) by using TaqI PCR-RFLP methods. Association analyses between this SNP and meat quality traits were performed using a general linear model (GLM) including sire effect. This SNP was significantly associated with backfat thickness $(P<0.05)$, marbling $(P<0.01)$. Interestingly, this SNP marker was also associated with volatile basic nitrogen after 14 days of storage $(P<0.05)$. To our knowledge, it is the first results observed for the $M C 4 R$ genotypes with volatile basic nitrogen after 14 days of storage in the commercial pig population. Therefore, these results suggest that the $M C 4 R$ gene can be targeted in marker-assisted breeding for selecting pigs with good meat quality.
\end{abstract}

Key words: commercial pig, $M C 4 R$, meat quality, sire effect, single nucleotide polymorphism

\section{INTRODUCTION}

Two major aspects of meat quality are nutritional quality and sensory quality. The former is usually objective because most nutritional traits are measurable quantities. On the other hand, sensory quality, including flavor, juiciness, tenderness, and color, is mostly qualitative, which is highly subjective; it is dependent on consumer preferences (Bender, 1992). These aspects are important because meat should be nutritious and healthy, satisfy consumer preferences, and be economically valuable. Over the last few decades, the improvement of live body weight while maintaining meat quality traits has become a major focus of the swine industry (Cisneros et al., 1996). Meat quality traits such as marbling, backfat thickness, juiciness, tenderness, color, $\mathrm{pH}$, fatty acid composition, and water holding capacity are important traits in pork because they are key factors that determine the compatibility of pork for storage, marketing display, packaging, and further manufacturing processes (Rosenvold and Andersen, 2003).

Thousands of quantitative trait loci (QTL) pertaining to economically important traits in swine have been

\footnotetext{
Department of Animal Science and Biotechnology, College of Agriculture and Life Sciences, Chungnam National University, Daejeon 305-764, Korea

2 Department of Animal Science, Faculty of Agriculture, Sebelas Maret University, Surakarta 57126, Indonesia

3 Department of Animal Science, Chungbuk National University, Cheongju 361-763, Korea

${ }^{4}$ Kuju Agricultural Research Center, Kyushu University, Kuju 4045-4, Taketa City, 878-020, Oita, Japan

* Corresponding author: (E-mail: junheon@cnu.ac.kr)
}

released by the National Animal Genome Research Program (NAGRP) (http://cn.animalgenome.org/cgi-bin/ QTLdb/index). Of these, 5406 QTLs are related to meat and carcass qualities. The existence of these data allows researchers to investigate and compare QTLs in diverse breeds and different populations. Additionally, this has made it possible to trace mutations in functional candidate genes for traits of interest. Utilization of wholegenome molecular data in swine breeding schemes has been conducted to ascertain the identities of loci that are responsible for phenotypic traits associated with meat quality and to develop marker assisted selection (MAS) techniques in the livestock industry (Dekkers, 2004). The use of MAS in swine breeding programs has been proven to be useful in the improvement of disease resistance, pork quality, carcass composition, reproductive traits, and growth related-traits (Ernst and Steibel 2013).

The melanocortin -4 receptor $(M C 4 R$ ) gene encodes a G-protein-coupled receptor expressed in the appetiteregulating areas of the brain that interact with adrenocorticotropic hormone and melanocyte-stimulating hormone (MSH) and is a member of the melanocortin receptor family. This gene family is involved in feed intake regulation and energy balance (Bruun et al., 2006; Fan et $a l ., 1997)$. The $M C 4 R$ gene is also expressed in placental and intestinal tissues. Mutations in the $M C 4 R$ gene have been reported to be associated with obesity in mice and humans (Huszar et al., 1997; Vaisse et al., 1998). In pigs, the $M C 4 R$ gene is one of the important candidate genes exhibiting positive correlations with meat quality traits. This gene has been mapped on Sus scrofa chromosome 1 (SSC1) by Kim et al. (2000a) located at $82.5 \mathrm{cM}$ (Rohrer et al., 2012), where a QTL region for meat qual- 
Table 1. Descriptive statistics for meat quality traits observed in this study

\begin{tabular}{lrrrr}
\hline Trait & Mean & SD & Min. & Max. \\
\hline Carcass weight (kg) & 86.95 & 5.19 & 74.00 & 102.00 \\
Backfat thickness (mm) & 23.03 & 5.11 & 13.00 & 39.00 \\
Moisture (\%) & 74.30 & 0.82 & 71.87 & 76.59 \\
Crude fat (\%) & 2.18 & 0.73 & 0.74 & 5.11 \\
Crude ash (\%) & 1.18 & 0.16 & 0.76 & 1.66 \\
Water holding capacity (\%) & 57.07 & 4.85 & 41.60 & 72.90 \\
Loin pH & 5.57 & 0.12 & 5.37 & 6.16 \\
Drip loss (\%) & 4.93 & 1.45 & 2.15 & 10.27 \\
Cooking loss (\%) & 31.31 & 2.96 & 22.20 & 40.73 \\
Shear force & 1192.53 & 319.51 & 513.33 & 2393.33 \\
Lightness (L) & 60.53 & 4.22 & 49.60 & 76.61 \\
Redness (a) & 6.80 & 1.86 & 1.96 & 13.39 \\
Yellowness (b) & 9.39 & 1.10 & 6.30 & 13.41 \\
Marbling score & 2.60 & 0.68 & 1.17 & 4.67 \\
Color score & 3.00 & 0.40 & 1.83 & 4.17 \\
Tenderness score & 2.87 & 0.31 & 1.83 & 3.67 \\
Volatile basic nitrogen (VBN) & 12.12 & 2.60 & 7.14 & 21.00 \\
VBN7 & 15.70 & 3.22 & 10.71 & 25.39 \\
VBN14 & 18.70 & 3.09 & 12.63 & 28.41 \\
Thiobarbituric acid (TBA) & 0.20 & 0.10 & 0.05 & 0.53 \\
TBA7 & 0.25 & 0.18 & 0.04 & 0.96 \\
TBA14 & 0.34 & 0.15 & 0.05 & 0.64 \\
\hline
\end{tabular}

Abbreviation: VBN7 and VBN14 are volatile basic nitrogen at 7 and 14 days of storage, respectively. TBA7 and TBA14 are thiobarbituric acid at 7 and 14 days of storage, respectively.

ity traits such as color, $\mathrm{pH}$, intramuscular fat traits, and marbling, was detected (Malek et al., 2001; Rohrer et al., 2012). Polymorphisms within the $M C 4 R$ gene have been reported and are known to be associated with significant variation in pork quality. For example, a missense mutation that replaces aspartic acid (Asp) with asparagine (Asn) at position 298 of the protein sequence of the $M C 4 R$ gene product (p.Asp298Asn) was associated with lean meat and backfat thickness in a Belgian commercial pig population, and a swine breed composite $\left(\mathrm{DIV}_{2}\right)$ population in China (Chao et al., 2012; Van den Maagdenberg et al., 2007). However, the effects of this mutation were not observed empirically and could not be validated in all investigated populations (Muñoz et al., 2012; Park et al., 2002; Stachowiak et al., 2006; Stinckens et al., 2009). Therefore, the objective of this study was to determine if the $M C 4 R$ gene was associated with meat quality traits in a commercial pig population in Korea. To this end we genotyped the c.892A>G (p.Asp298Asn) single nucleotide polymorphism (SNP) by using polymerase chain reaction-restriction fragment length polymorphism (PCR-RFLP) analysis.

\section{MATERIALS AND METHODS}

\section{Animals and phenotypes}

Among the total of 593 pigs sampled from a commer- cial population (generated by the three-way cross breeding system using Landrace, Yorkshire, and Duroc, from seven different farms), sire information was retrieved from 232 pigs. These animals were used in this association study. The pig sub-population investigated was obtained from six different farms, which used 10 sires to generate a total of 232 piglets (121 castrated males and 111 females). Sire, sex, and carcass weight were included as covariates in the linear model to analyze carcass and meat quality traits (Table 2). They were reared and managed in controlled conditions in each farm by intensively concerning animal rights. Carcass traits were collected immediately after slaughtering.

Backfat thickness data were collected at the $10^{\text {th }}$ and $11^{\text {th }}$ of ribs at Longissimus dorsi (LD) area. Furthermore, meat quality traits including $\mathrm{pH}$, marbling, tenderness, water holding capacity (WHC), cooking loss, drip loss, shear force, and proximate composition analysis were measured at 24 hours after the slaughter, while volatile basic nitrogen (VBN) and thiobarbituric acid (TBA) were calculated at 1, 7 and 14 days after slaughtering. Loin steak was used and weighed before and after cooking at $70^{\circ} \mathrm{C}$ in 40 minutes for both cooking loss and shear force measurement using Warner-Bratzler shear force meter. In addition, meat colors, lightness (L), redness (a), yellowness (b), were also observed following Commission International de Leclairage (CIE) protocol. 


\section{DNA extraction and genotypes}

Muscle tissue was used to extract and isolate genomic DNA using $20 \mathrm{mg} / \mathrm{mL}$ proteinase $\mathrm{K}$ digestion followed by phenol extraction. A primer pair previously described by Meidtner et al. (2006) and Fan et al. (2009), 5'-TCGATTGCAGTGGACAGGTA-3' as a forward primer and 5'-GAAAATGCTGTTGTTGAAGCA-3' as a reverse primer, were used to isolate $663 \mathrm{bp}$ of exon one of the $M C 4 R$ gene. The PCR was carried out to isolate the $M C 4 R$ gene in $25 \mu \mathrm{L}$ volume containing $25 \mathrm{ng}$ per $\mu \mathrm{L}$ DNA genome, $0.01 \mu \mathrm{M}$ primers, $5 \mathrm{mM}$ of dNTP, $2.5 \mu \mathrm{L}$ of 10X PCR reaction buffer, 0.625 units of $h-T a q$ DNA polymerase (Solgent, Korea), and water. The PCR reaction was performed using PTC-200 thermocycler machine (MJ Research, USA). Reaction condition was pre-denaturation at $95^{\circ} \mathrm{C}$ for 15 minutes, and followed by 40 cycles of denaturation at $95^{\circ} \mathrm{C}$ for 20 seconds, 20 seconds at $62^{\circ} \mathrm{C}$ of annealing temperature, extension at $72^{\circ} \mathrm{C}$ for 30 seconds, final extension was carried out at $72^{\circ} \mathrm{C}$ for 5 minutes. Then, the PCR products were visualized using $2 \%$ agarose gel electrophoresis. To verify the SNPs, previously PCR products were purified using Geneclean turbo kit (MP Biomedicals, USA), and then they were sequenced using Applied Biosystems 3730 DNA sequencer (PE Applied Biosystems, USA). Furthermore, sequence data were anlyzed to investigate point of mutation using Sequencher ver 4.7 (Gene codes, USA).
Polymerase chain reaction-restriction fragment length polymorphism (PCR-RFLP) was performed to genotype a dbSNP (dbSNP Acc. No. 107793985) which is also known as c.892A $>$ G SNP (Asp298Asn). This marker was recognized by TaqI restriction enzymes. The PCR products were digested using 2 units of each restriction enzymes for more than 6 hours under optimal reaction conditions (Biolabs ${ }^{\circledast}$ Inc., USA). Then, digested PCR products were separated and visualized by $2.5 \%$ of MetaPhor $^{\circledast}$ agarose gel (LONZA, USA) electrophoresis for 40 minutes.

\section{Statistical Analysis}

Association between the SNP marker of $M C 4 R$ and meat quality traits was evaluated using a general linear model (GLM) implemented in MINITAB version 14.0 (Minitab Inc., USA). The mathematical model used in this study was as follows:

$$
\begin{aligned}
Y_{\mathrm{ijklm}} & =\mu+\text { Sex }_{i}+\text { Genotype }_{j}+\text { Farm }_{k}+\text { Sire }_{1(k)} \\
& +b_{1} C W_{i \mathrm{jklm}}+\varepsilon_{\mathrm{ijkmm}}
\end{aligned}
$$

Where, $Y_{\mathrm{i} \mathrm{k} k \mathrm{~m}}$ is the phenotype of the $\mathrm{m}^{\text {th }}$ animal, $\mu$ is the overall mean, Sex $x_{\mathrm{i}}$ is the effect of sex, Genotype is the effect of the genotype, Farm $_{\mathrm{k}}$ is the effect of the farm, Sire $_{1(k)}$ is the effect of the $\mathrm{l}^{\text {th }}$ Sire nested within the $\mathrm{k}^{\text {th }}$ Farm, $C W_{\text {ijklm }}$ is the effect of carcass weight as a covari-

\begin{tabular}{|c|c|c|c|c|c|c|c|c|}
\hline \multirow{2}{*}{ Trait } & \multicolumn{2}{|c|}{ Sex } & \multicolumn{2}{|c|}{ Farm } & \multicolumn{2}{|c|}{ Sire } & \multicolumn{2}{|c|}{ CW } \\
\hline & Adj $\mathrm{MS}^{\S}$ & $F$-value & Adj MS & $F$-value & Adj MS & $F$-value & Adj MS & $F$-value \\
\hline BF thickness & 506.49 & $35.39 * * *$ & 124.57 & $8.70 * * *$ & 235.92 & $16.48^{* * *}$ & 182.86 & $12.78^{* * *}$ \\
\hline Moisture & 0.2326 & 0.42 & 2.8232 & $5.10 * * *$ & 4.7889 & $8.65^{* * *}$ & 0.6186 & 1.12 \\
\hline Crude fat & 2.9301 & $5.98^{*}$ & 1.2430 & $2.54^{*}$ & 1.2023 & $2.45^{*}$ & 0.8786 & 1.79 \\
\hline Crude ash & 4.289 & 0.96 & 1.492 & 0.34 & 4.840 & 1.09 & 1.364 & 0.31 \\
\hline WHC & 59.42 & 3.49 & 267.16 & $15.69 * * *$ & 67.47 & $3.96 * *$ & 14.32 & 0.84 \\
\hline Loin $\mathrm{pH}$ & 0.0305 & 2.47 & 0.0303 & $2.45^{*}$ & 0.0353 & $2.86^{*}$ & 0.0088 & 0.71 \\
\hline Drip loss & 0.025 & 0.01 & 13.910 & $7.54 * * *$ & 3.922 & 2.13 & 0.407 & 0.22 \\
\hline Cooking loss & 4.923 & 0.90 & 100.368 & $18.36 * * *$ & 70.771 & $121.95 * * *$ & 0.209 & 0.04 \\
\hline Shear force & 11768 & 0.15 & 540261 & $7.11 * * *$ & 1213139 & $15.97 * * *$ & 791 & 0.01 \\
\hline $\mathrm{L}$ & 37.23 & 2.22 & 46.16 & $2.76 *$ & 43.33 & $2.59 *$ & 38.60 & 2.30 \\
\hline $\mathrm{a}$ & 0.679 & 0.23 & 15.799 & $5.37 * * *$ & 3.759 & 1.27 & 4.698 & 1.60 \\
\hline $\mathrm{b}$ & 7.830 & $6.94^{* * *}$ & 3.370 & $2.99 *$ & 1.107 & 0.98 & 0.069 & 0.06 \\
\hline Marbling score & 0.5411 & 1.26 & 0.8666 & 2.01 & 1.5232 & $3.54 * *$ & 0.0936 & 0.22 \\
\hline Color score & 0.3917 & 2.58 & 0.2168 & 1.43 & 0.1795 & 1.18 & 0.1971 & 1.30 \\
\hline Tenderness score & 0.0281 & 0.31 & 0.2945 & $3.30 * *$ & 0.0763 & 0.85 & 0.1559 & 1.75 \\
\hline VBN & 1.321 & 0.89 & 85.818 & $57.77 * * *$ & 305.187 & $205.43 * * *$ & 3.119 & 2.10 \\
\hline VBN7 & 1.84 & 1.05 & 174.87 & $99.68 * * *$ & 368.92 & $210.29 * * *$ & 2.98 & 1.70 \\
\hline VBN14 & 6.47 & 2.86 & 239.64 & $106.02 * * *$ & 107.55 & $47.58^{* * *}$ & 1.29 & 0.57 \\
\hline TBA & 0.0107 & 2.31 & 0.07695 & $16.62^{* * *}$ & 0.19478 & $42.07 * * *$ & 0.01306 & 2.82 \\
\hline TBA7 & 0.00053 & 0.05 & 0.75087 & $71.23^{* * *}$ & 0.25360 & $24.06^{* * *}$ & 0.01109 & 1.05 \\
\hline TBA14 & 0.02604 & $4.39 *$ & 0.59972 & $101.20 * * *$ & 0.09520 & $16.07 * * *$ & 0.00059 & 0.10 \\
\hline
\end{tabular}

Table 2. Significance effect of sire, sex and carcass weight (CW) on the meat quality phenotypes

$\S$ Adjusted mean squares; $* P<0.05 ; * * \mathrm{P} P<0.01 ; * * * P<0.001$ 
ate, and $\varepsilon_{\mathrm{ijkm}}$ is random error. The Tukey's test was also performed to differentiate between genotypes. The threshold for the significance was set at $P<0.05$.

\section{RESULTS}

The c.892A $>$ G SNP of the $M C 4 R$ gene has been successfully genotyped by PCR-RFLP method. All three known genotypes of this SNP, AA (71), AG (111), and GG (50), were detected, and they obeyed HardyWeinberg equilibrium $\left(\chi^{2}=0.7339\right.$, d.f. $\left.=1, \mathrm{P}>0.10\right)$. Therefore, this SNP marker was used for subsequent association study.

Descriptive statistics, including mean, standard deviation (SD), and minimum (Min.) and maximum (Max.) values, of 22 meat quality and carcass traits are summarized in Table 1. Furthermore, this study revealed that sire and farm were robustly affecting pork quality traits and sex was affecting backfat thickness, yellowness, and TBA14 (Table 2).

Association analysis between the $M C 4 R$ gene polymorphism and carcass and pork quality traits was performed using all 232 animals (Table 3). This SNP marker was associated with marbling score $(P<0.01)$, signifi- cantly affected backfat thickness at the 10th and 11th ribs $(P<0.05)$, and was significantly associated with volatile basic nitrogen $(\mathrm{VBN})$ at 14 days of storage $(P<0.05)$. Individuals carrying an A allele of the c.892A $>\mathrm{G}$ SNP presented higher marbling scores than those carrying the $G$ allele (Table 3). The mean of marbling score of homozygous AA individuals was 2.8, as opposed to 2.4 in homozygous GG individuals. These scores suggest that this population has abundant marbling in intramuscular fat. At the same time, pigs with the AA genotype presented higher backfat thickness than homozygous GG individuals. In addition, heterozygous AG pigs exhibited lower VBN in pork after 14 days of storage compared to other genotypes (Table 3).

\section{DISCUSSION}

A number of confirmation studies have been reported regarding polymorphisms which are spread on the promoter and exon regions of the $M C 4 R$ gene. A total of 41 variants have been compiled at the National Center for Biotechnology Information (NCBI) (http://www.ncbi. nlm.nih.gov/snp). Some of these porcine $M C 4 R$ gene variants have been discussed in the literature, and their

Table 3. The effects of MC4R c.892A $>$ G SNP on meat quality traits in the commercial pig population

\begin{tabular}{|c|c|c|c|c|}
\hline \multirow{2}{*}{ Trait } & \multicolumn{3}{|c|}{ Genotype } & \multirow{2}{*}{$P$-value } \\
\hline & $\mathrm{AA}^{\dagger}$ & $\mathrm{AG}^{\dagger}$ & $\mathrm{GG}^{\dagger}$ & \\
\hline Backfat thickness (mm) & $23.20 \pm 0.48^{\mathrm{a}}$ & $22.76 \pm 0.38 \mathrm{a}$ & $21.29 \pm 0.55 b$ & $0.024^{*}$ \\
\hline Moisture (\%) & $74.20 \pm 0.095$ & $74.26 \pm 0.075$ & $74.40 \pm 0.110$ & 0.363 \\
\hline Crude fat (\%) & $2.2543 \pm 0.090$ & $2.166 \pm 0.075$ & $2.098 \pm 0.085$ & 0.243 \\
\hline Crude ash (\%) & $1.203 \pm 0.014$ & $1.205 \pm 0.011$ & $1.202 \pm 0.017$ & 0.987 \\
\hline WHC (\%) & $57.28 \pm 0.530$ & $57.64 \pm 0.414$ & $57.43 \pm 0.604$ & 0.849 \\
\hline Loin pH & $5.579 \pm 0.014$ & $5.554 \pm 0.011$ & $5.536 \pm 0.016$ & 0.119 \\
\hline Drip loss (\%) & $4.839 \pm 0.173$ & $4.954 \pm 0.137$ & $4.830 \pm 0.199$ & 0.805 \\
\hline Cooking loss (\%) & $31.61 \pm 0.298$ & $31.68 \pm 0.236$ & $31.79 \pm 0.343$ & 0.920 \\
\hline Shear force & $1210 \pm 35.11$ & $1199 \pm 27.74$ & $1211 \pm 40.35$ & 0.954 \\
\hline $\mathrm{L}(\mathrm{CIE}-\mathrm{L})$ & $60.96 \pm 0.521$ & $60.30 \pm 0.413$ & $60.80 \pm 0.560$ & 0.547 \\
\hline a (CIE-a) & $6.753 \pm 0.218$ & $6.616 \pm 0.173$ & $6.809 \pm 0.251$ & 0.771 \\
\hline $\mathrm{b}(\mathrm{CIE}-\mathrm{b})$ & $9.366 \pm 0.137$ & $9.521 \pm 0.107$ & $9.398 \pm 0.156$ & 0.603 \\
\hline Marbling score ${ }^{1}$ & $2.790 \pm 0.084^{\mathrm{a}}$ & $2.630 \pm 0.066^{\mathrm{ab}}$ & $2.397 \pm 0.096^{\mathrm{b}}$ & $0.008^{* *}$ \\
\hline Color score ${ }^{2}$ & $2.974 \pm 0.050$ & $2.997 \pm 0.039$ & $3.003 \pm 0.057$ & 0.906 \\
\hline Tenderness score ${ }^{3}$ & $2.917 \pm 0.038$ & $2.872 \pm 0.030$ & $2.838 \pm 0.044$ & 0.370 \\
\hline VBN (mg\%) & $12.32 \pm 0.148$ & $12.14 \pm 0.117$ & $12.10 \pm 0.170$ & 0.522 \\
\hline VBN7 & $15.60 \pm 0.161$ & $15.48 \pm 0.127$ & $15.56 \pm 0.185$ & 0.835 \\
\hline VBN14 & $18.97 \pm 0.183 a$ & $18.38 \pm \pm 0.144^{\mathrm{b}}$ & $18.76 \pm 0.211^{\mathrm{ab}}$ & $0.026^{*}$ \\
\hline TBA (mgMA/kg) & $0.179 \pm 0.009$ & $0.183 \pm 0.007$ & $0.173 \pm 0.010$ & 0.728 \\
\hline TBA7 & $0.222 \pm 0.013$ & $0.226 \pm 0.010$ & $0.213 \pm 0.015$ & 0.770 \\
\hline TBA14 & $0.326 \pm 0.010$ & $0.322 \pm 0.008$ & $0.318 \pm 0.0113$ & 0.844 \\
\hline
\end{tabular}

${ }^{1}$ Marbling, 1 indicates extremely low in intramuscular fat and 5 indicates very abundant in intramuscular fat ${ }^{2}$ Meat color, 1 indicates very pale and 5 indicates very dark

${ }^{3}$ Tenderness, 1 indicates very tough, very dry, and very mild. 5 indicates very tender, very juicy, and very intense. ${ }^{\dagger}$ Represents Least Square Means (LSM) \pm Standard Error (SE)

*Represents that the genotypes affect the traits significantly $(* P<0.05)$ and highly significant $(* * P<0.01)$ 
effects to the pork quality have shown different results (Bruun et al., 2006; Fan et al., 2009; Kim et al., 2000b; Meidtner et al., 2006; Muñoz et al., 2012; Ovilo et al., 2006; Park et al., 2002; Stachowiak et al., 2006; Stinckens et al., 2009). In this study, c.892A > G SNP was mapped in order to investigate its effects on economically important quantitative traits. The minor allele frequency of c.892A $>$ G SNP was almost equal to that of the major allele frequency, and was also in Hardy-Weinberg equilibrium, therefore, it was used for subsequent association study.

Association analysis between the $M C 4 R$ gene polymorphism and carcass and pork quality traits was performed using all 232 animals (Table 3). The c.892A>G SNP marker was tightly associated with marbling score $(P<0.01)$ and significantly affected backfat thickness at the 10th and 11th ribs $(P<0.05)$. Individuals carrying an A allele of the c.892A $>$ G SNP presented higher marbling scores than those carrying the $\mathrm{G}$ allele (Table 3 ). The mean of marbling score of homozygous AA individuals was 2.8, as opposed to 2.4 in homozygous GG individuals. These scores suggest that this population has abundant marbling in intramuscular fat. At the same time, pigs carrying AA genotype presented higher backfat thickness than homozygous GG individuals. Van den Maagdenberg et al. (2012) reported that the c.892A>G SNP of the $M C 4 R$ gene was associated with fat thickness, with pigs carrying the AA genotype presenting higher fat thickness. The same effect was also discovered in the commercial pig population assessed in this study. Moreover, the significance association of c.892A>G SNP to the marbling score implied that it may play an important role in swine fat deposition, particularly in the muscle (Davoli et al., 2012). In addition, the c.892A $>\mathrm{G}$ SNP was also significantly associated to the volatile basic nitrogen $(\mathrm{VBN})$ at 14 days of storage $(P<0.05)$ which is heterozygous AG pigs contained lower VBN in pork after 14 days of storage compared to other genotypes (Table 3). It may be the first report of an association between variants of the $M C 4 R$ gene with VBN content. Huang et al. (2014) explained that VBN is one of the most important reference indexes to evaluate pork freshness. A lower VBN content indicates fresher pork. Therefore, this novel finding may be useful as a marker for selecting for pork freshness.

In summary, our findings confirmed that the c.892A $>$ G SNP is a promising molecular marker for pork fatness, especially high marbling score and backfat thickness. With respect to VBN content, further studies are necessary to confirm and validate the results of our study in other swine populations.

\section{ACKNOWLEDGEMENTS}

This work was supported by a grant entitled "Development of genetic improvement systems in pigs using genomic and reproductive technologies" from the Korea Institute of Planing and Evaluation for Technology of Food, Agriculture, Forestry and Fisheries. This work also supported by the CNU research grant 2014 at
Chungnam National University in Korea.

\section{REFERENCES}

Bender, A. 1992 Meat and meat products in human nutrition in developing countries. In "FAO Food and Nutrition Paper \#53", Food Policy and Nutrition Division of FAO 2: 1-88

Bruun, C. S., C. B. Jorgensen, V. H. Nielsen, L. Andersson and M Fredholm. 2006 Evaluation of the porcine melanocortin 4 receptor (MC4R) gene as a positional candidate for a fatness QTL in a cross between Landrace and Hampshire. Anim. Genet., 37: 359-362

Chao, Z., F. Wang, C. Y. Deng, L. M. Wei, R. P. Sun, H. L. Liu, Q. W. Liu and X. L. Zheng. 2012 Distribution and linkage disequilibrium analysis of polymorphisms of $M C 4 R$ LEP H-FABP genes in the different populations of pigs associated with economic traits in DIV2 line. Mol. Biol. Rep., 39: 6329-6335

Cisneros, F., M. Ellis, F. K. McKeith, J. McCaw and R. L. Fernando. 1996 Influence of slaughter weight on growth and carcass characteristics commercial cutting and curing yields and meat quality of barrows and gilts from two genotypes. J. Anim. Sci., 74: $925-933$

Davoli, R., S. Braglia, V. Valastro, C. Annarratone, M. Comella, P. Zambonelli, I. Nisi, M. Gallo, L. Buttazzoni and V. Russo. 2012 Analysis of MC4R polymorphism in Italian Large White and Italian Duroc pigs: Association with carcass traits. Meat Sci., 90: $887-892$

Dekkers, J. C. 2004 Commercial application of marker- and geneassisted selection in livestock: strategies and lessons. J. Anim. Sci., 82 E-Suppl: E313-E328

Ernst, C. W., and J. P. Steibel. 2013 Molecular advances in QTL discovery and application in pig breeding. Trends Genet., 29: $215-224$

Fan, W., B. A. Boston, R. A. Kesterson, V. J. Hruby and R. D. Cone. 1997 Role of melanocortinergic neurons in feeding and the agouti obesity syndrome. Nature, 385: 165-168

Fan, B., S. K. Onteru, G. S. Plastow and M. F. Rothschild. 2009 Detailed characterization of the porcine MC4R gene in relation to fatness and growth. Anim. Genet., 40: 401-409

Huang, L., J. Zhao, Q. Chen and Y. Zhang. 2014 Nondestructive measurement of total volatile basic nitrogen (TVB-N) in pork meat by integrating near infrared spectroscopy computer vision and electronic nose techniques. Food Chem., 145: 228-236

Huszar, D., C. A. Lynch, V. Fairchild-Huntress, J. H. Dunmore, Q. Fang, L. R. Berkemeier, W. Gu, R. A. Kesterson, B. A. Boston, R. D. Cone, F. J. Smith, L. A. Campfield, P. Burn and F. Lee. 1997 Targeted disruption of the melanocortin-4 receptor results in obesity in mice. Cell, 88: 131-141

Kim, K. S., N. J. Larsen and M. F. Rothschild. 2000a Rapid communication: linkage and physical mapping of the porcine melanocortin-4 receptor (MC4R) gene. J. Anim. Sci., 78 : 791-792

Kim, K. S., N. Larsen, T. Short, G. Plastow and M. F. Rothschild. 2000b A missense variant of the porcine melanocortin-4 receptor (MC4R) gene is associated with fatness growth and feed intake traits. Mamm. Genome, 11: 131-135

Malek, M., J. C. Dekkers, H. K. Lee, T. J. Baas, K. Prusa, E. HuffLonergan and M. F. Rothschild. 2001 A molecular genome scan analysis to identify chromosomal regions influencing economic traits in the pig II Meat and muscle composition. Mamm. Genome, 12: 637-645

Meidtner, K., A. K. Wermter, A. Hinney, H. Remschmidt, J. Hebebrand and R. Fries. 2006 Association of the melanocortin 4 receptor with feed intake and daily gain in F2 Mangalitsa x Pietrain pigs. Anim. Genet., 37: 245-247

Muñoz, G., E. Alcázar, A. Fernández, C. Barragán, A. Carrasco, E. de Pedro, L. Silió, J. L. Sánchez and M. C. Rodríguez. 2011 Effects of porcine MC4R and LEPR polymorphisms gender and Duroc sire line on economic traits in DurocIberian crossbred pigs. Meat Sci., 88: 169-173

Ovilo, C., A. Fernández, M. C. Rodríguez, M. Nieto and L. Silió. 
2006 Association of MC4R gene variants with growth fatness carcass composition and meat and fat quality traits in heavy pigs. Meat Sci., 73: $42-47$

Park, H. B., O. Carlborg, S. Marklund and L. Andersson. 2002 Melanocortin-4 receptor (MC4R) genotypes have no major effect on fatness in a Large WhitexWild Boar intercross. Anim. Genet., 33: 155-157

Rohrer, G. A., D. J. Nonneman, R. K. Miller, H. Zerby and S. J. Moeller. 2012 Association of single nucleotide polymorphism (SNP) markers in candidate genes and QTL regions with pork quality traits in commercial pigs. Meat Sci., 92: 511-518

Rosenvold. K., and H. J. Andersen. 2003 Factors of significance for pork quality-a review. Meat Sci., 64: 219-237

Stachowiak, M., M. Szydlowski, M. Obarzanek-Fojt and M. Switonski. 2006 An effect of a missense mutation in the porcine melanocortin-4 receptor (MC4R) gene on production traits in Polish pig breeds is doubtful. Anim. Genet., 37: 55-57

Stinckens, A., T. Luyten, K. Van den Maagdenberg, S. Janssens, S. De Smet, M. Georges and N. Buys. 2009 Interactions between genes involved in growth and muscularity in pigs: IGF-2 myostatin ryanodine receptor 1 and melanocortin-4 receptor. Domest. Anim. Endocrinol., 37: 227-235

Vaisse, C., K. Clement, B. Guy-Grand and P. Froguel. 1998 A frameshift mutation in human MC4R is associated with a dominant form of obesity. Nat. Genet., 20: 113-114

Van den Maagdenberg, K., A. Stinckens, E. Claeys, M. Seynaeve, A. Clinquart, M. Georges, N. Buys and S. De Smet. 2007. The Asp298Asn missense mutation in the porcine melanocortin-4 receptor (MC4R) gene can be used to affect growth and carcass traits without an effect on meat quality. Animal, 1 1089-1098 